\title{
The Creativity of Designing Batik Serumpun Melayu Through Indonesian-Malaysian Cultural Acculturation
}

\author{
Shaari ${ }^{5}$ \\ ${ }^{I}$ Faculty of Letters, Universitas Negeri Malang, pujiyanto.fs@um.ac.id \\ ${ }^{2}$ Faculty of Letters, Universitas Negeri Malang, robbyhidajat.fs@um.ac.id \\ ${ }^{3}$ Faculty of Letters, Universitas Negeri Malang,Swastikadhestianggriani.fs@um.ac.id \\ ${ }^{4}$ Faculty of Engineering, Universitas Negeri Malang, nurulaini.ft@um.ac.id \\ ${ }^{5}$ Faculty of Design and Architecture Universiti Putra Malaysia, nazlinashaari@upm.edu.my
}

Pujiyanto ${ }^{1}$, Robby Hidajat ${ }^{2}$, Swastika Dhesti Anggriani ${ }^{3}$, Nurul Aini ${ }^{4}$, Nazlina

\begin{abstract}
The occurrence of claiming the cultural results of one country makes other countries unwilling to release because they feel that the culture that other countries claim belongs to them. This condition causes the relationship between the two countries to be less harmonious. If viewed from the Malayan's history, the two countries have the same family culture, namely the Malayan culture. This culture can be used to explore and produce a new Malayan culture, one of which is the batik, which is characterized by a Malayan family culture. "Batik Serumpun Melayu". Data were collected through observations in several cities in the Sumatera region to Kuala Lumpur to produce the "Batik Serumpun Melayu". The interviews were conducted with resource persons who knew the Malayan culture, as well as document data in the form of artifacts from past Malayan culture to strengthen the data. Through this research, data objects are used as a source of ideas in the creation of "Batik Serumpun Melayu". Through the acculturation approach of Indonesian-Malaysian culture, a creative process of Design Thinking from Plattner, Meinel \& Weinberg in the form of understanding, observe, point of view, ideate, prototype, and test to produce the batik "Relung Mekar Melayu" which has had Intellectual Property Right (HKI). It is hoped that the batik's invention is expected to unite the Malayan culture, which means to unite the Indonesian-Malaysian culture in the batik "Relung Mekar Melayu" which is shared, worked together and developed together.
\end{abstract}

Keywords: cultural acculturation, creativity, design thinking, batik Melayu

\section{INTRODUCTION}

When a country wants to dominate, own, and clamp down on cultural products in the form of batik, this can damage the two countries' harmony. It happened between Indonesia and Malaysia over the ownership of batik that has long been owned by each country. If this problem keeps up, it will undoubtedly be detrimental to the two "Serumpun Melayu" countries, which will result in unfavorable diplomatic relations. If we pay attention to Indonesia's and Malaysia's geographical location, they are a neighboring country in an Asian region known as a Malayan family country. Geographically and ideologically, these two countries share the common ancestor of the Malayan people. One of the Malayans has the same ideology, namely Islam. According to Gaspersz (2018), Islam is the identity of the Malayan community; people "convert to Islam" means being "Malayan people", or "being Malayan" means "convert to Islam". The integration of religion, traditions, and art in the Malayan culture make life aspects integrated into the Malayan community's life. One of them is the art with local cultural values that contain ideology that adheres to the view of life as a link to social life in the form of Malayan traditions (Aslan, 2017). Tambak (2017) explains that Malayan culture is closely related to traditions, social patterns, and government systems. The elements and cultural results are attached to language, literature, arts, crafts, and technology that lead to local wisdom so that Malayan local culture continues.

According to Sunandar (2015), in the scope of Islamic Malayan culture as local culture, it develops constructively, making people believe in and obey the Almighty, who is considered to regulate their daily lives. The system of community values and religious beliefs has survived even though globalization, such as information and communication technology and lifestyle influences, influences society. Therefore, according to Karmel (2015), a comprehensive concept related to society, culture, economy, technology, text, and the context is needed in facing the global world. Based on its details, characters, characteristics, types, and variations, Malayan culture is easily recognized. This formalization will be easy to carry out preservation, excavation, and 
traditional arts development program based on Malayan culture (Ahimsa, 2015).

The character of the Malayan community is the basis for creating "Batik Serumpun Melayu". To create "Batik Serumpun Melayu", there are problems need to be explored, including: (1) How to understand the problems that occur between the two countries of Indonesia and Malaysia related to the recognition of cultural results, (2) How to observe the results of Malayan family culture which can be integrated into cultural acculturation Indonesia with Malaysian culture, (3) What is needed by prospective users in a "Batik Serumpun Melayu" design, (4) How to extract ideas on cultural products in the form of artifacts in the two countries that can be used as "Batik Serumpun Melayu" designs, (5) How to design a design prototype into several alternative colors that suit the user and their function, and (6) How the results of the "Batik Serumpun Melayu" designs are applied to fashion.

To answer some of the problems mentioned above, the research team provided a solution by exploring Malayan artifacts as the basis for developing "Batik Serumpun Melayu" by acculturating IndonesianMalaysian culture. Through cultural acculturation in realizing the Malayan family of batik, it is hoped that there will be no more clampers of these products so that the two countries can harmonize and unite in developing the results of the Malayan culture. The acculturation of Indonesian and Malaysian, Malayan cultural artifacts developed through the design thinking process will produce "Batik Serumpun Melayu". The realization of Malayan batik as common property, so that they both own them and develop them and a medium to strengthen allied regions and countries.

\section{RESEARCH METHOD AND DESIGN}

Before designing the "Batik Serumpun Melayu", a research was conducted with a qualitative descriptive approach. This research took data from several sources through observation, documents, and literature. Direct observations were made in 6 Malayan cultural museums: Museum Negeri South Sumatera, Istana Maimun Medan South Sumatera, Museum Nagari Adityawarman West Sumatera, Museum Sang Nila Utama Riau, National Muzium Malaysia, dan Muzium Diraja Malaysia. From the observations in several museums, data on artifacts of decorative wood carvings on the Nagari Adityawarman Padang museum walls and the Malaysian museum of Diraja were obtained. Verbal data is needed in symbols attached to these cultural objects through library data to strengthen visual data on wood carving decorations. The data were sorted, selected, and grouped, adapted from the various forms of decorative wood carvings with threedimensional characters that were hard to develop into two-dimensional batik motifs with soft characteristics. The development of wooden carvings into batik works brought closer to the Malay culture requires a design process. According to Plattner, Meinel \& Weinberg in designing "Batik Serumpun Melayu" works can be done through a tinking design process which consists of the stages of understanding, observe, point of view, ideate, prototype, and test (Mueller \& Roterberg, 2018), (Figure $1)$.

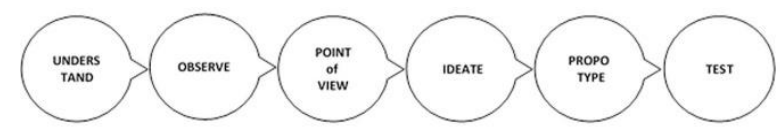

Figure 1 Plattner, Meinel \& Weinbergmaka's Design Thinking Creativity Process (Mueller \& Roterberg, 2018)

\section{RESULT AND DISCUSSION}

The Malayan family's batik in Sumatra has a different style from the batik that developed in Java. For example, Riau Malayan batik has existed since the days of the Kerajaan Daek Lingga, which originated from the Malayan culture of Indonesia, Malaysia, and Singapore. The research results by Sahara, Efi, Fitria, and Hadiastuti (2018) that Riau Malayan batik is characterized by its motif in a veil whose arrangement leads to vertical lines, mostly in the form of flora creeping upwards.

Meanwhile, Padang batik is known as batik tanah liek (clay) because the process used to be clay. During its development, Padang batik explored artifacts in the Minangkabau area, such as the Gadang House, the Jam Gadang (clock tower), Tabuik, the Malin Kundang ship Rangkiang (Oktora and Adriani, 2019). The design is not rigid; the artifact's object is combined with the creeping flora as a supporting motif. The flora referred to include sirih Gadang, jasmine flowers, rayo flowers, which function as supporting motifs in the appearance of batik patterns.

Malayan batik rarely shows a human or animal figure but is often dominated by vegetation motifs (Info Batik, 2019). Similarly, Malayan batik develops in Aceh visually shows a combination of flora objects, geometric shapes, and local cultural artifact objects. Aceh batik is rarely found a showing motif that raises ideas from animals because the local people believe that there is a prohibition in Islam sharia from showing animate creatures (Cahbagoes, 2017).

If Malayan batik in Indonesia is juxtaposed with Malayan batik in Malaysia, Malaysian batik has a flower motif similar to Indonesian batik. It is because, among others, some Pekalongan and Ponorogo people moved to and stayed in Malaysia in the 1970s. Cultural acculturation makes the pattern of batik existing in Indonesia similar to Malaysia (Supriono, 2017). According to Kari, Samin, and Legino (2018), as an understanding of Islam, Malaysia does not like fauna motifs, so that many flora motifs are found. The types of flora that adorn Malaysian batik are floral motifs, such as bongor flowers (Kedah), kesidang flowers (Malaka), candlenut flowers (Pahang), bougainvillaea flowers 
(Silver), alamanda flowers (Terengganu), chili flowers (Negeri Sembilan), mango flowers (Perlis), lundu orchid (Sarawak), tanjung flowers (Selangor), rafflesia flowers (Sabah), and gambir flowers (Johor).

Closely observed, Malayan batik developing in Indonesia often uses flower motif one of which is jasmine. This flower is trendy in Indonesia and makes Indonesia well-known for this holy and fragrant flower in the house yard. Similarly, hibiscus is so well-known in Malaysia that it made its national flower or Malaysian grand flower (Bunga Raya Malaysia). Therefore, it is unsurprising that these two flowers often inspire an idea to adorn craft product surfaces like batik in same-root Malayan areas (Figure 2). in an art crisis conflict because one state feels another takes its cultural product. Pros and cons claiming for another state's cultural product and artwork make their relationship less harmonious. It occurs in batik artwork leading to the suit filed to United Nations Educational Scientific and Cultural Organizations (UNESCO) to maintain its ownership.

This condition makes the research team interested in looking for a solution for the two states concerning the claim or competition for the cultural product in the form of art.
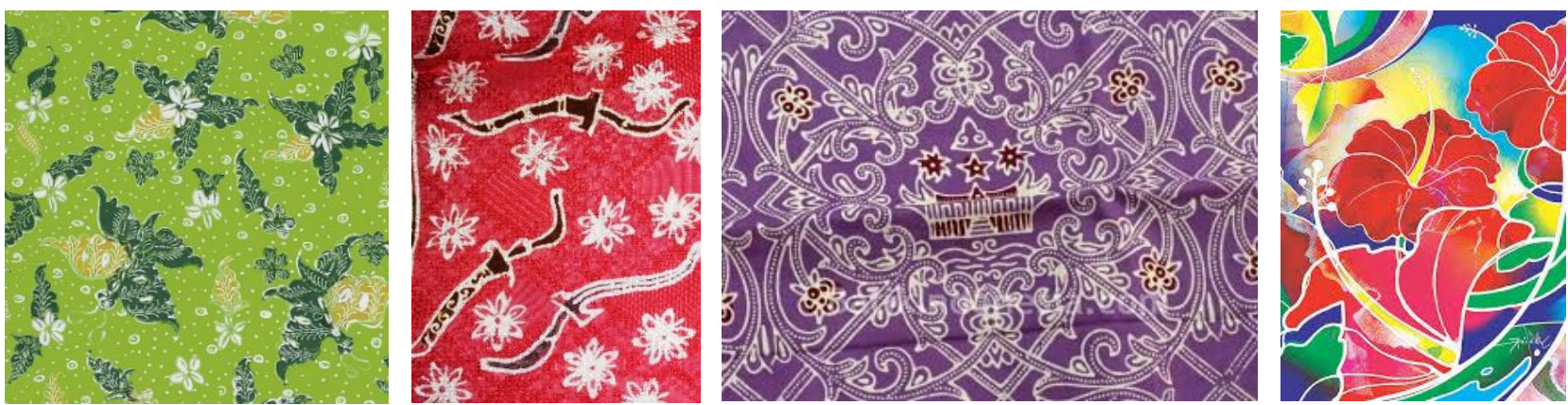

Figure 2 Riau-star Flower Motif, Aceh Dagger (Rencong) motif, Padang Motif, and Kuala Lumpur Hibiscus Motif (https://gambarsempurna.blogspot.com; https://fasnina.com; https://gpswisataindonesia.wordpress.com; http://alonabatik.com)

As Malayan states, Indonesia and Malaysia have past cultural heritages such as artifacts stored in museums. Those artifacts can underlie the creation of "Batik Serumpun Melayu", different from batik products existing within society. New batik created through designing creativity produces new batik but still with typical characteristics of the Malayan culture. For the batik to have typical Malayan cultural characteristics, cultural acculturation should occur between Indonesia and Malaysia, creating a new culture featuring their own culture, such as "Batik Serumpun Melayu" combining Malayan cultural products both countries. This new "Batik Serumpun Melayu" is the joint (collective) property, and it can be developed corresponding to their areas and states. Indonesian-Malaysian cultural acculturation process in designing "Batik Serumpun Melayu" is conducted through the design thinking creativity process, from understanding, observing, point of view, ideate, prototype, and test.

\subsection{Understand}

Indonesia and Malaysia are fellow Malayan states with the same cultural root, so that their social culture is not far different. Closed observed, there are also visual similarities in physical evidence like traditional house architecture, local costume, and other cultural products. However, Indonesia and Malaysia are recently involved
An attempt taken is to explore cultural acculturation between Indonesia and Malaysia continuously to result in an evolution of culture that, in turn, will create a new culture in the form of art that will belong to the two states collectively. The new cultural product intended is batik originating from the past artifacts but with a new appearance.

The natural environment in the form of past artifacts and the social environment of people of the Malayan family can shape creativity through imagination (Sugiarto, 2019). Through both states' recognition, batik produced can be developed continuously and thereby traded as the creative economic product. "Batik Serumpun Melayu" results in good diplomatic relations between Indonesia and Malaysia so that there will be no more conflict occurring due to the need for an interest in art.

\subsection{Observe}

In this stage, the author conducted observation on the Malayan cultural product as decoration or motif inherent to the past artifacts. The artifacts are stored in museums in same-root Malayan areas. Therefore, the observation was conducted on 4 Malayan museums in Indonesia and 2 in Malaysia. The museums observed in Indonesia were (1) Istana Maimun Medan in Sumatera Utara (North 
Sumatera) Province, (2) Museum Negeri in Sumatera Utara (North Sumatera) Province, (3) Museum Sang Nila Utama in Riau Province, and (4) Museum Nagari Adityawarman in Sumatera Barat (West Sumatera) Province. Two museums observed in Malaysia were: (1) Muzium Diraja Malaysia and (2) National Muzium Malaysia. Having observed all the museums, the author was interested in the decoration inherent to the wall of Museum Nagari Adityawarman Padang, West Sumatera Province, and Muzium Diraja Malaysia on Istana Street, Istana Negara Wilayah Persekutuan Kuala Lumpur Malaysia. Through observation, the author could respond quickly to the situation, and the environment made the primary subject of thinking in batik design through the creative application (Burnette, 2020). The research team's responsiveness through formative execution of thoughts and actions based on ideas, processes, and values in decorative forms in the form of wood carvings was creatively developed into a "Batik Serumpun Melayu" (Burnette, 2020). The choice of wood-carving decoration is made because of its similar shape and hollow character, making it easy to be combined with batik motif through cultural acculturation (Figure 3). creative process by transferring an idea from the preexisting object to be developed in an interdisciplinary manner, thereby creating something new.

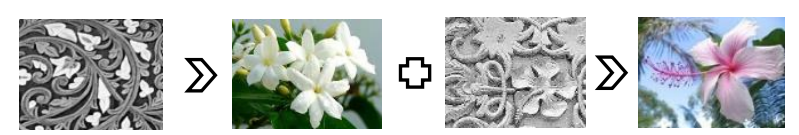

Figure 4. Jasmine and Hibiscus inspiring an idea of wood carving in Museum Nagari Adityawarman Padang and Muzium Diraja Malaysia (Author's Documentation; https://ekonomi.bisnis.com; https://bibitbunga.com)

The choice of two flower objects means crystallizing idea into a batik motif representing two states through cultural acculturation in jasmine widespread in Indonesia and hibiscus popular in Malaysia. In designing "Batik Serumpun Melayu", data of potential users were required. Demographically the potential users are adult women aged 21-40 years, geographically staying in Malayan areas, particularly psychographically having maturity in taking action and behavior and doing the activity outside the home more frequently.
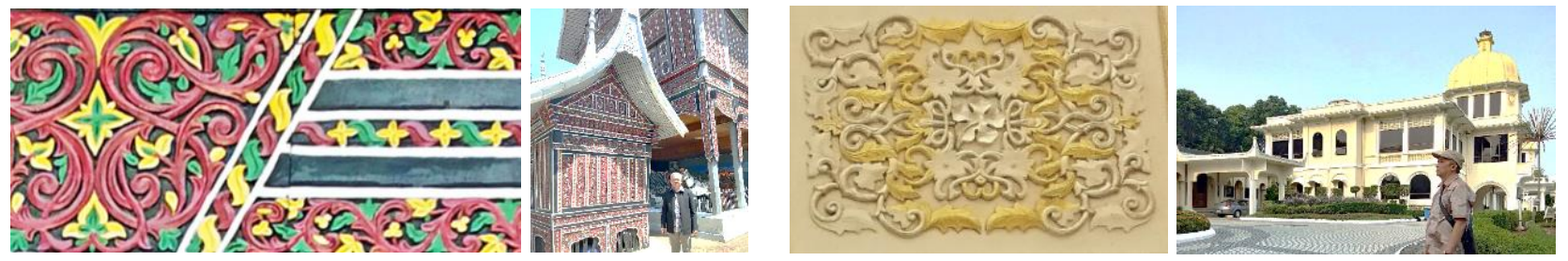

Figure 3 Carving in Museum Nagari Adityawarman in West Sumatera Province and Muzium Diraja Malaysia (Author's Documentation)

\subsection{Point of View}

Viewed from the need for designing, the author should give a solution to society's needs. For the design to be more quality, the discussion should be conducted, and the team to explore individual researchers' creativity to create new work. The research team paid attention to wood carving on the wall of Museum Nagari Adityawarman Padang in West Sumatera and Muzium Diraja Malaysia in Kuala Lumpur Malaysia, on which there is a flower shape often used to adorn other objects. In designing a product, an artist, a craftsman, or designer is sometimes influenced by the environment where they work because the environment can support the working process by giving motivation, experience, and meaning to them (Wilson, 2016). There are jasmine and hibiscus in their environment that can influence their thoughts and ideas in creating visual work such as wood carving decoration (Figure 4)

Similarly, in designing a batik motif originating from the idea of jasmine and sunflower, there is the interior esthetic element of wood carving existing in the museum. According to Ryden and Sposato (2020), this view is a
This period is a productive one to have offspring, and it is a group having a shared understand-ding of social activity within society (Putri, 2019). Considering the marketing's target market, this "Batik Serumpun Melayu" seems to be religious to its users.

\subsection{Ideate}

The idea is related to creeping plants combined with jasmine and hibiscus. The creeping plants useful to human beings grow widely in tropical regions like Indonesia and Malaysia. The fragrant flowers are often used for trimming in sacred ceremonies in an area, e.g., a wedding ceremony. Jasmine, as an Indonesian flower, often becomes the typical characteristics of Indonesian batik. Then, hibiscus, as a typical characteristic of the Malaysian flower, attracts the viewers' attention. These three elements underlie the design of IndonesianMalaysian-style "Batik Serumpun Melayu". These three elements can be simplified through the deformation process in stalk and flower shapes producing new shapes (Figure 5). 

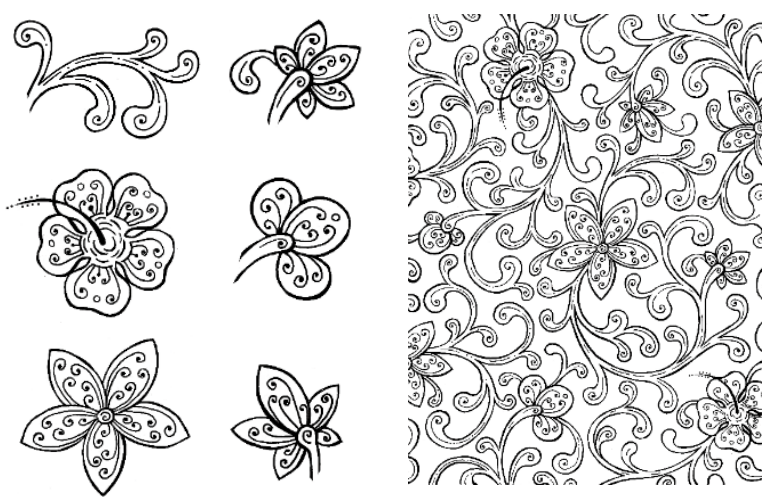

Figure 5 Jasmine and Hibiscus stalks and flowers bunched into one pattern of Batik Design (Author's Documentation)

In idea processing, creative culture must try something new, different from the previous one as the most creative method (Galton, 2015). The new shape resulting from the deformation process is combined with and integrated into a pattern. As creative thinking, an original design processing is required to feature batik more; therefore, the primary and supporting motives are filled with batik character corresponding to adult women's function. According to Zubaedi (2017), creativity is the ability, attitude, and process of designing batik. Ability to think and build new ideas by combining and changing existing works into something new. There is an attitude in the designer to accept change and renewal through a flexible game of ideas through different perspectives to produce different works. Creativity is a process that is carried out continuously through evolution to produce better and new batik designs.

\subsection{Prototype}

The basic idea translated into a sketch is then developed into a prototype as the chosen design. In producing the batik design prototype, some points should be considered: material, process technology, function, and target market. The research team should adjust the color of the batik motif precisely. The designing of batik "Relung Mekar Melayu" focuses more on hibiscus and jasmine figures in a bright color as the primary motif. In contrast, the figure of creeping plants with soft color serves as the supporting motif. Two figure objects and two-color groups are combined into one pattern, thereby producing a beautiful batik "Relung Mekar Melayu". As alternative colors, 5 (five) different color sample prototypes are prepared with the same character, adjusted with the adult women as the target users (Figure 6).

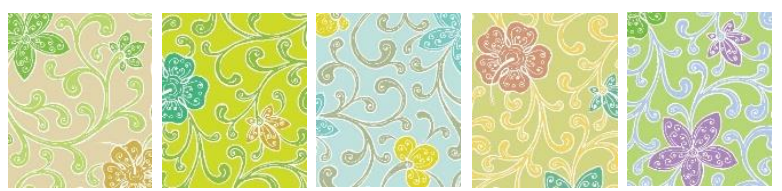

Figure 6 Prototype of Five Alternative Colors in Batik "Relung Mekar Melayu” (Author's Document)
When the Batik is worn, it will give a softer, elegant, fascinating, and lively impression; therefore, the soft color is featured and combined with a little bright color. For the design product to be tidier and better, computer program, particularly Adobe Photoshop and adobe illustrator programs, is needed to process pattern and color to produce the design prototype more quickly. Computer technology in creativity can accelerate design through engineering to produce innovative batik art that has added value that is useful in people's lives (Pujiyanto, 2019).

For the users to know the symbolical meaning of the motif in batik "Relung Mekar Melayu", an explanation is required concerning this motif. This motif batik has a basic idea deriving from wood-carving decoration on the wall of buildings of Museum Nagari Adityawarman Padang in West Sumatera Province and Muzium Diraja Malaysia in Kuala Lumpur Malaysia. This motif is a combination of Indonesian and Malaysian cultural products processed through acculturation. Visually, this batik motif sways to the right-to the left and up-down, spreading over the entire cloth surface. The fashion designers will cut it more efficiently and freely following their mode design. Besides, the motif creeping to the right and left symbolizes human life in the world sometimes on the right side as the life undertaking Allah's instruction and some other times on the left side as when it is tempted by the satan break His (Allah) instruction. Up-down direction symbolizes the livelihood (rezeki) obtained by human beings, sometimes it is up (much), and some other times it is down (a little). Whatever Allah gives, as His creature, we should remain to be grateful. There are two figure groups in this batik: jasmine representing Indonesia and hibiscus representing Malaysia, combined into batik "Relung Mekar Melayu" as the symbol of fragrance. When adult women wear this batik, they are expected to get happiness in family and a good reputation in the social environment.

\subsection{Test}

When the batik "Relung Mekar Melayu" design has been created, it should be trialed by applying it to adult women's fashion. According to Kartajaya (2017), this motif product should be implemented to determine the actual output (product). If it has not been applied yet, it is considered as having not implemented the actual creativity. The trial should be conducted obligatorily to find out this batik motif's compatibility to the users, ergonomically, and psychographically. If a result has been satisfied, this motif would have been registered its copyright in the Republic of Indonesia's Ministry of Law and Human Rights. As a result, on June 26, 2020, the motif of batik "Relung Mekar Melayu" has had Intellectual Property Right (HKI) Number 000194363 
from the Republic of Indonesia's Ministry of Law and Human Rights (Figure 7).

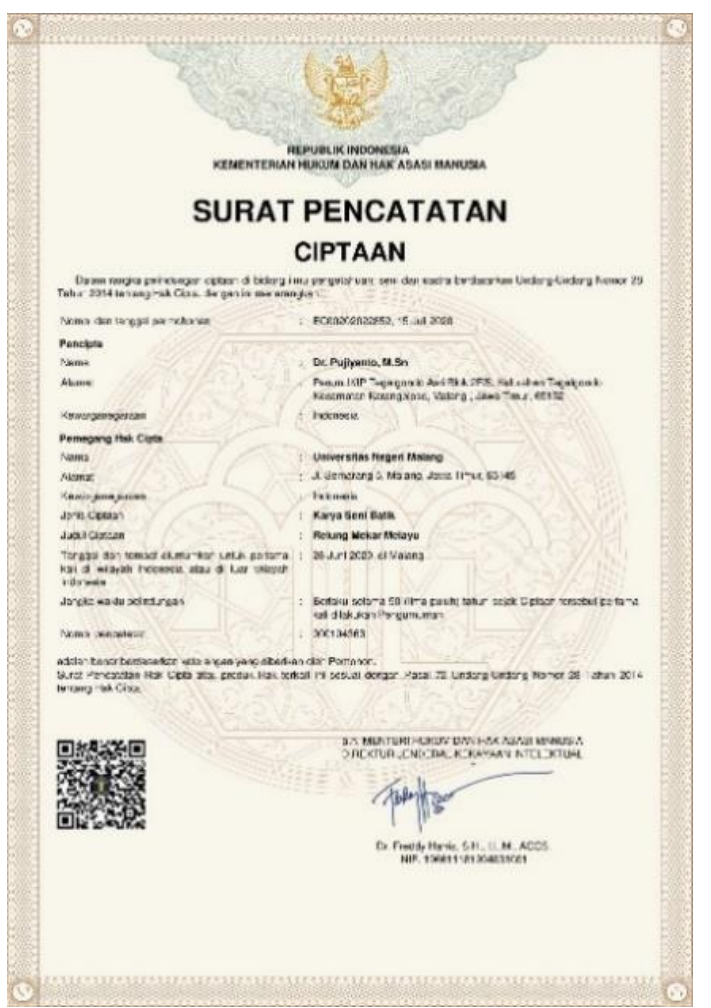

Figure 7 HKI Certificate for Batik "Relung Mekar Melayu" (Author's Documentation)

The trial of batik "Relung Mekar Melayu" was conducted on the Muslimah fashion model for adult women to make those wearing it more beautiful, softer, and more prestigious. From the trial result, there seems to be compatibility of current trend fashion through contemporary design, from the past traditional artifact product into present modern batik product.

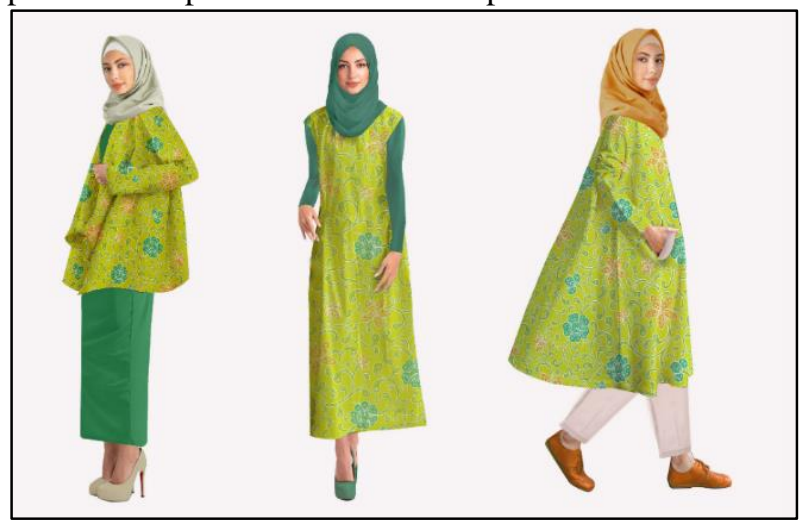

Figure 8 Female Models wearing Batik "Relung Mekar Melayu” confidently (Author's Document)

The women wearing this batik feel up to date and always following design development, particularly "Batik Serumpun Melayu". Batik designed by fully adorning the cloth surface is flexible for any Muslim fashion models. This batik can be combined with a plain cloth or the one with the same motif but different color, thereby giving a different accent. This batik motif's flexibility attracts the women who want to appear more fashionable, corresponding to Islam Sharia (Figure 8).

\section{CONCLUSION}

For the countries of the Malayan family to remain united, a unifying medium is needed, one of which is through the batik that originates from the Malayan culture. "Serumpun Melayu" countries, such as Indonesia and Malaysia, need a new culture owned by the two countries through the acculturation of the two countries' cultures. The mixing of these cultures is in the form of existing artifacts, and then the creative process stages of the design thinking are carried out so that the batik art "Relung Mekar Melayu" is created. The art of batik is rooted in the artifacts of Malayan culture, which is full of Islam and is aimed primarily at the Malayan community's women. As an understanding of Islamic law, this batik does not display animate motifs, but in the form of creeping plants. To attract more attention, the batik contains jasmine flower motifs as typical of the Indonesian state combined with shoeblackplant flowers as typical of Malaysia. If this batik is used, the hope is that the wearer will become a pious person, fragrant in the community's family environment and dignity. Through the Malayan family of batik art that is jointly owned and recognized by Indonesia and Malaysia, it is free to develop. The existence of the batik art "Relung Mekar Melayu" as a foundation in developing good motifs of Melalu in various styles and styles as a creative economic product. In the future, the batik art of a Malayan family batik can be used as an object of work to be joint actors and fashion shows between Indonesian and Malaysian designers in the "Serumpun Melayu" cultures' packaging.

\section{REFERENCES}

[1] Ahimsa, Heddy Shri and Putra. (2015). Seni Tradisi, Jatidiri dan Strategi Kebudayaan, Jurnal Ilmu Sosial Mamangan, (Traditional Art, Self Identity and Cultural Strategy. Mamangan Journal of Social Science). Volume 2, Number 1, January-June 2015_12

[2] Aslan. (2017). Nilai-Nilai Kearifan Lokal Dalam Budaya Pantang Larang Suku Melayu Sambas, Jurnal Ilmu Ushuluddin (Local Wisdom Values in Taboos Culture of Sambas Malayan Tribe, Journal of Ushuluddin Science) Volume 16 Number 1, June 2017

[3] Burnette, Charles H. (2020). Self, Society, Culture and Design, https://www.academia.edu/ 42973930/Self_Society_Culture and Design_4 
[4] Burnette, Charles. (2020) The Process of Design Thinking, https://www.academia.edu/ 3737301/ Creativity in Design Thinking, 01/07/2020_1

[5] Cahbagoes. (2017). Sejarah Motif Batik Aceh dan Penjelasannya (History of Aceh Batik Motif and Its Explanation). https://batik-tulis.com/blog/ batikaceh, accessed on July 30, 2020

[6] Galton, Maurice. (2015). Final report of the project: The Pedagogy of Creative Practitioners in Schools, England: Faculty of Education, University of Cambridge_76

[7] Gaspersz, Steve G. Chr. (2018). Masuk Melayu Menegosiasikan Islam dan Kemelayuan di Malaysia, Civic-Culture: Jurnal Ilmu Pendidikan PKn dan Sosial Budaya (Entering into Malayan Negotiates Islam and Malayanism in Malaysia, Civic Culture: Journal of Civic and Social-Cultural Education), Volume 2 Number 2, October 2018_8

[8] Info Batik. (2019). Batik Tabir, Batik Baru Khas Riau, https://infobatik.id, accessed on July 2, 2020

[9] Kari, Rabiatuadawiyah Mohd., Samin, Mohd Azhar and Legino, Rafeah. (2018). Sustainability of Traditional Motifs in Malaysian Batik Block. International Journal of INTI, Faculty of Art \& Design, Universiti Teknologi MARA, Volume 22, Special Issue, December 2018_80-81

[10] Karmel, Siti Heidi. (2015). Batik dan Tenun: Cerminan Budaya Melayu Bagian dari Ekonomi dan Industri Kreatif di Kota Jambi, Jurnal Ilmiah Universitas Batanghari Jambi (Batik and Woven Cloth: A Reflection of Malayan Culture, a Part of Creative Economy and Industry in Jambi City, Scientific Journal of Batanghari University of Jambi), Vol.15 No.4 of 2015_152-153

[11] Kartajaya, Hermawan. (2017). Citizen 4.0: Menjejakkan Prinsip-prinsip Pemasaran Huma-nis di Era Digital (Citizen 4.0: Applying Humanistic Marketing Principles in Digital Era), Jakarta: Kompas Gramedia_166 \& 213.

[12] Mueller, Christian \& Roterberg. (2018). Handbook of Design Thinking Tips \& Tools for how to design thinking, https://www. researchgate.net/publication/329310492_6

[13] Oktora, Nana and Adriani. (2019). Studi Batik Tanah Like Kota Padang. Journal Gorga, Volume 8 Number 1 (2019), https://jurnal.unimed.ac.id/ 2012/index.php/gorga/ article/view/12879

[14] Pujiyanto. (2019). Pemanfaatan Teknologi Informasi Komunikasi Dalam Berkarya Desain Bagi Anak Millennial "Generasi Z" dalam seminar Nasional Pendidikan Seni Alternatif di Era Millenial
Berbasis Nilai-nilai Luhur Nusantara, Malang: Universitas Negeri Malang_22

[15] Putri, Alifia Fernanda. (2019). Pentingnya Orang Dewasa Awal Menyelesaikan Tugas Perkembangannya (The Importance of Early Adult Completiing Their Developmental Duty) SCHOULID: Indonesian Journal of School Counseling. Universitas Negeri Padang, (2019), 3(2)_35-40

[16] Ryden, Wendy snd Danielle Sposato. (2020). Cultivating Convergence through Creative Nonfiction: Identity, Development, and the Metaphor of Transfer, Journal of Creative Writing Studies, Vol 5 [2020], Iss. 1, Art. 2_1-20

[17] Sahara, Nita., Efi, Agusti., Fitria, Reni., and Hadiastuti, Hadiastuti. (2018). Desain Ragam Hias Pelaminan Melayu Riau Sebagai Inspirasi Inovasi Kriya Batik. Journal Gorga, Volume 7 Number 2 (2018), https://jurnal.unimed.ac.id/ 2012/ index.php/gorga/article/view/11854

[18] Sugiarto, Eko. (2019). Kreativitas, Seni \& Pembelajarannya, Yogyakarta: LKiS_18,40,55

[19] Sunandar. (2015). Melayu Dalam Tantangan Globalisasi: Refleksi Sejarah dan Berubahnya Sistem Referensi Budaya, Jurnal KhatulistiwaJournal of Islamic Studies (Melayu in Globalization Challenge: Reflection of History and the Change of Cultural Reference System, Journal of Khatulistiwa - Journal of Islamic Studies), Volume 5 Number 1, March 2015_68-72

[20] Supriono, Primus. (2017). Ensiklopedia The Heritage Of Batik-Identitas Pemersatu Kebanggaan Bangsa (Encyclopedia The Heritage Of BatikNation Pride Unifying Identity), http://alonabatik. com/berita/detail/sejarah-teknik-perintang warnadi-malaysia-42372.html\#sthash.oPCFg2vV.dpuf, 29 September 2017

[21] Tambak, Syahraini and Desi Sukenti. (2017). Implementasi Budaya Melayu Dalam Kurikulum Pendidikan Madrasah Ibtidaiyah di Riau, Journal MIQOT (Implementation of Malayan Culture in the Education Curriculum of Islamic Primary School, Journal of MIQOT) Vol. XLI No. 2 July-December 2017-364

[22] Wilson, Kate. (2016). Critical Reading, Critical Thinking: Delicate Scaffolding in English for Academic Purposes (EAP). Thinking Skills and Creativity http://dx.doi.org/10.1016/j.tsc.2016. $\underline{10.002} 1-18$

[23] Zubaedi. (2017). Strategi Taktis Pendidikan Karakter, Jakarta: Rajawali Pres_10 